\title{
Fictional Objects, edited by Stuart Brock and Anthony Everett
}

DOI:

10.1080/00048402.2016.1241291

\section{Document Version}

Accepted author manuscript

Link to publication record in Manchester Research Explorer

\section{Citation for published version (APA):}

Caddick Bourne, E. (2016). Fictional Objects, edited by Stuart Brock and Anthony Everett. Australasian Journal of Philosophy, 95(4), 810-813. https://doi.org/10.1080/00048402.2016.1241291

\section{Published in:}

Australasian Journal of Philosophy

\section{Citing this paper}

Please note that where the full-text provided on Manchester Research Explorer is the Author Accepted Manuscript or Proof version this may differ from the final Published version. If citing, it is advised that you check and use the publisher's definitive version.

\section{General rights}

Copyright and moral rights for the publications made accessible in the Research Explorer are retained by the authors and/or other copyright owners and it is a condition of accessing publications that users recognise and abide by the legal requirements associated with these rights.

\section{Takedown policy}

If you believe that this document breaches copyright please refer to the University of Manchester's Takedown Procedures [http://man.ac.uk/04Y6Bo] or contact uml.scholarlycommunications@manchester.ac.uk providing relevant details, so we can investigate your claim.

\section{OPEN ACCESS}


This is an electronic version of a book review published in Australasian Journal of Philosophy Vol 95 Issue 4 (2017), pp.810-813. The Australasian Journal of Philosophy is available online at: http://www.tandf.co.uk/journals/ and the published version of this book review is available at: https://www.tandfonline.com/doi/full/10.1080/00048402.2016.1241291

Brock, Stuart and Anthony Everett, eds., Fictional Objects, Oxford: Oxford University Press, 2015, pp. vii $+299, £ 45.00$ (hardback).

Bringing together eleven essays on fictional and mythical objects, their (non-)existence, nature, and identity, and the content of our talk and thought about them, Stuart Brock and Anthony Everett's edited collection Fictional Objects breaks new ground in debates about fictional things and our relations to them.

One achievement is to range significantly beyond the case of fictional characters. The book does not forget how important characters are to the philosophy of fiction, and contributors offer many new ideas about this central type of fictional object, but they also consider fictional properties (e.g. Sarah Sawyer's chapter), kinds (e.g. David Braun's), and groups or collections (e.g. Frederick Kroon's). Several papers emphasise not the relatively highly-specified characters we typically expect to encounter in novels or films - Anna Karenina, Harry Potter, etc. - but objects which are sparsely described. Robert Howell and Nathan Salmon both consider how to understand 'a witch' and 'she' in Peter Geach's famous Hob/Nob sentence. The very short stories considered by Ben Caplan and Cathleen Muller say little to characterise the persons they seem to be about. Brock and Everett's introduction includes a brief but interesting discussion of fictional parts. (They suggest that the ways in which talk about fictional things can isolate parts from wholes raises a question, at least for realist theories, of whether to countenance many additional fictional objects corresponding to parts. They concentrate on spatial parts, but the idea could, I suggest, be extended to temporal stages. For 
instance, a later character may be modelled on an earlier character in their such-and-such phase, that is, as they are in a particular segment of their fictional life.)

Fictional Objects considers mythical objects, as well as objects associated with stories typically taken by their audiences and originators to be fiction. How do these two themes relate? The editors make suggestions - that intentional identity is a common concern, for example - but I think the question is left largely unresolved. This did not make the book any less satisfying, but did make me wonder whether there is a philosophically interesting reason why the question is not resolved. How a theory of fictional objects is to constrain, and be constrained by, a theory of mythical objects will depend, I think, upon what kind of representation a fiction is. Is fiction's capacity to represent parasitic on other forms of representation (for instance, non-fiction, or states of imagination)? What is it for a representation to be a fiction? What is it for a fiction to have content at all? There are certainly points in the book which relate to such questions, but its core concern is with the nature of objects rather than the nature of fictions as representations. There may be features of contemporary discussions of fiction, particularly of realist approaches, which naturally encourage separating what fictional objects are from how fiction represents. For instance, the strategy Kroon identifies as 'Divide-and-Rule' [164] demarcates claims about characters as characters (which may be abstract objects, authorially-created objects, non-existent objects, etc.) from the fiction's representation of whatever it is about (which may be persons, talking pigs, etc.). See also Thomasson [255-6]. Reintegrating the nature of fictional representation into a metaphysics of fictional objects may point the way to clarifying the relationship between the 'fictional' and 'mythical' objects considered here, through clarifying whether a fiction's relations to what it represents are mediated in the same way as a theory's.

In the first essay of Fictional Objects, William G. Lycan argues that fictional characters are (nonexistent) nonactual objects, and that their identity is determined not qualitatively, but by their haecceity. Lycan defends the view against objections from Kripke's work on reference and 
fictionality. I would recommend this book to anyone interested in Kripke's position(s), which also receive detailed attention in some other chapters.

In chapter 2, Robert Howell proposes that audiences' nonconscious processing of texts involves an assumption that names rigidly designate an object at the world the text concerns. This facilitates 'semantic descent' from metalinguistic claims and thoughts, to claims and thoughts such as Anna Karenina is a woman, which can be evaluated as true within the scope of the assumption.

In chapter 3, David Braun offers objections to Kripke's and Salmon's views of fictional and mythical objects, and defends the view that some utterances involving fiction or erroneous theoretical posits ('unicorn', 'Vulcan', etc.) express gappy propositions. Part of Braun's argument is that somebody can rationally produce an utterance when the proposition it expresses would equally be expressed by an utterance they wish not to make. This strategy is of particular interest, I suggest, given the prominent role played in the metaphysics of fiction by considerations of what audiences and critics can acceptably say.

In chapter 4, Nathan Salmon develops his view of mythical objects, focussing particularly on Geach's 'Hob thinks a witch has blighted Bob's mare, and Nob wonders whether she (the same witch) killed Cob's sow'. The sentence, Salmon proposes, says that something is in common between Hob's and Nob's thoughts which is either a real witch (a woman with supernatural powers) or a mythical witch (a non-material thing, represented as being a real witch). For Salmon, mythical objects are 'an unavoidable by-product of human fallibility' [119], brought into existence inadvertently by 'misbelievers' making 'theoretical mistakes' [127]. An interesting complication would arise, I think, if it is sometimes indeterminate whether a theoretical mistake is made. Postulating future entities for instance, a new type of creature which may or may not come about as a result of a present biological experiment - may be one such case. If the future is open, then the facts concerning what exists and what does not are arguably insufficient either to furnish a real creature, or to generate, in combination with the theoretician's postulation, a mythical object. If persuasive versions of Geach's 
sentence can be constructed for contexts where it is indeterminate whether a mistake has been made, then it is an interesting question, for Salmon's account, what role mythical objects play in these.

In chapter 5, Alberto Voltolini defends 'syncretism': fictional entities are generated by taking a reflexive stance on a process of make-believe storytelling, whereby it is seen as involving a certain set of properties (those the story attributes to the relevant thing). Next, in chapter 6, Frederick Kroon challenges a semantic argument for the view that fictional objects are created abstract objects. If the 'creationist' is right that certain sentences commit to the existence of particular, discernible fictional objects, then there are also sentences which commit us to an indefinite number of indiscernible abstract fictional objects: a reductio, Kroon proposes, of the creationist argument.

In Chapter 7, Ben Caplan and Cathleen Muller argue that some stories make it arbitrary whether or not character $\mathrm{x}$ is identical with y. 'A Curious New Shop' (henceforth 'Curious') tells us that a man entered the shop and a man left, but says, 'It's indeterminate whether the curious man who came [in] ... is the curious man who left' [181]. Caplan and Muller briefly consider, but reject, the alternative of saying that there are (determinately) no fictional characters in such stories (see 'Haukioja's Answer' [194]). I would like to take this alternative further, however, by saying that 'Curious' stops short of being a complete fiction. It gives not enough information to describe a fictional world where one person enters and leaves, nor enough to describe a world where one enters and another leaves. Since no fictional world is described, no characters are described. 'Curious' begins in the vein of something that could be a fiction, if it went further, but resists going far enough. Its explicit mentions of indeterminateness cannot, on this reading, be taken literally as reporting facts about identities in a fictional world. But they could be read as self-conscious comments on its (deliberate) failure to determine either a one-customer or a two-customer world as fictional. Caplan and Muller's insistence that fictional realists would be inclined to utter sentences like 'Fred is a fictional character that comes from ['Curious'], as is George; and, according to that 
story, they are indeterminately identical' [195] probably stands, as a claim about what 'Curious' might make us want to say. But how does it make us want to say this? Not necessarily by representing facts about identity which escape finitely statable, informative identity-conditions. Perhaps, instead, it seems that we can think about Fred and George as characters of 'Curious' because we can think about the characters there would have been had the story developed differently - into a fiction which describes two customers, or a fiction which describes one. On this reading, engaging with 'Curious' trades on imagining the fictions it could have been, but isn't. Of course, this is only the beginnings of a response to Caplan and Muller's intriguing argument.

In chapter 8, Sarah Sawyer argues that many accounts of fictional characters rely on an unmotivated assumption, and one which sometimes conflicts with other aspects of the theories: that some predicates refer to (purely) fictional properties. Suggesting a pretence-based antirealism as the way forward, Sawyer argues that treating terms as if they refer is common between engagement with fiction and with logic. In Chapter 9, Stuart Brock defends treating sentences which might otherwise motivate realism as prefixed with 'According to the realist's theory'. This fictionalist treatment risks invalidating desirable patterns of inference, by construing some premises as prefixed and others not. Brock preserves the inferences by accepting additional premises about realism as a theory (such as that it is deductively closed). In chapter 10, Amie L. Thomasson defends her 'deflationary realism' from the objection that the ontological claims it accepts should be understood as uttered in pretence. The objection backfires, Thomasson argues. It leaves the objector - but not the deflationist - needing to articulate what more it would be for there to really be fictional characters.

In chapter 11, Anthony Everett and Timothy Schroeder propose that fictional characters are ideas, had in devising ways to tell stories. They argue that ideas should be individuated in terms of their origins, but aim to incorporate talk which seems to individuate ideas by their contents by saying that ordinary practices of individuation are 'interest relative, context sensitive, and in many instances simply sloppy' [277]. Here I have doubts: interest relativity and context sensitivity are different from 
sloppiness. If judgements of what is what are genuinely to be evaluated relative to an interest, and if our interest is sometimes in contents, then it is not clear why individuation by content should be, as Everett and Schroeder suggest, misindividuation. This qualm does not, however, undermine the interest of Everett and Schroeder's novel proposal.

I enjoyed Fictional Objects very much. All of its chapters are rich in argument, creative in their ideas, and food for thought for anyone interested in fictionality and its relations to existence, possibility, thought, and language.

Emily Caddick Bourne Institute of Continuing Education, University of Cambridge Department of Philosophy, School of Humanities, University of Hertfordshire e.caddick@herts.ac.uk 